\title{
Treatment of retrograde peri-implantitis: seven-year follow-up study
}

\author{
Ju-Youn Lee* \\ Department of Periodontology, School of Dentistry, Pusan National University, Yangsan, Republic of Korea
}

Retrograde peri-implantitis (RPI) is defined as a clinically symptomatic periapical lesion. RPI is generally accompanied by symptoms of pain, tenderness, swelling and fistula. Several etiologic factors of RPI were possible, residual bacteria would be the main cause of RPI. Various treatment modalities have been introduced: debridement only or a combination of debridement with the grafting material accompanied by a detoxification of the infected implant surfaces, apicoectomy and so on. Although the definitive management methods remain undefined, many favorable clinical results of a treatment of RPI have been published. This case report introduces the 7-year long-term clinical result of the application the principle: implant surface detoxification using saline and chlorhexidine and guided bone regeneration with bone graft material and barrier membrane. If the implant was not mobile, it would be possible to treat RPI according to surgical approach and good results will be maintained over long term. (J Dent Rehabil Appl Sci 2014;30(3):259-64)

Key words: peri-implantitis; alveolar bone graft; bone regeneration; membrane

\section{서론}

임플란트의 높은 성공률로 인해 치과 진료 형태에 많 은 발전을 가져왔다. 그러나 최근 단일 치아의 임플란트 증례가 많이 증가하면서 인접치아의 염증상태와 발치된 치조제의 잔존 염증 상태의 상호 영향에 대한 우려가 증 가되고 있다.

역행성 임플란트 근단병소 주위염(Retrograde Periimplantitis, RPI)은 임플란트 식립 후 임플란트 고정체 (fixture)의 치관측은 정상적인 골-임플란트 계면을 확립 하고 있는 반면, 임상적으로 증상이 동반된 근단부의 방 사선 투과성 병소로 정의된다. ${ }^{1}$ 이러한 임상적 상황이 많 은 연구자들에 의해 보고되었고, 임플란트 부위, 발거된 치아 또는 인접 치아에서의 세균 감염 또는 임플란트 식 립 시의 열 발생, 과도한 교합력의 적용 등에 의해 야기

*Correspondence to: Ju-Youn Lee, DDS, PhD

Department of Periodontology, School of Dentistry, Pusan National University 20 Geumo-ro, Mulguem-eup, Yangsan, 626-787, Republic of Korea Tel: +82-55-360-5202, Fax: +82-55-360-5194, E-mail: heroine@pusan.ac.kr Received: April 10, 2014/Last Revision: August 5, 2014/Accepted: August 10, 2014
된다고 하였다. ${ }^{2,3} \mathrm{RPI}$ 는 종종 동통, 경결감, 부종, 누공 등 의 증상을 수반하게 된다. 이는 임플란트 식립을 위한 골 창 형성 후 형성된 골창의 길이보다 짧은 임플란트가 식 립 되거나 열에 의해 유발된 무균성의 골 괴사에 의해 야 기되는 임상적으로 증상이 없는 근단부 병소와는 구분되 어야 한다. ${ }^{2,3}$

RPI의 유병율은 539개의 임플란트를 후향적으로 조사 한 연구에서, abutment를 연결하기 전 상악 $1.6 \%$, 하악 $2.7 \%$ 에서 관찰되었다. ${ }^{4}$ 이러한 RPI의 가능한 원인으로 는 임플란트 부위의 박테리아의 잔존, ${ }^{3}$ 인접치의 치근단 병소, ${ }^{4}$ 인접치와의 최소 거리 침범, 골 삭제시의 과열 ${ }^{2}$ 등 을 들 수 있다.

RPI를 치료하고 임플란트를 유지하기 위해 다양한 치 료 방법 또는 치료법의 조합들이 소개되고 있다 ${ }^{3}$ : 인접치 근관치료, ${ }^{5}$ 염증 조직 제거(debridement) 단독 시행, ${ }^{3,4}$ 또

Copyright@ 2014 The Korean Academy of Stomatognathic Function and Occlusion. (c) It is identical to Creative Commons Non-Commercial License. 
는 차폐막 동반 또는 동반하지 않은 골이식재 적용, ${ }^{4}$ 감 염된 임플란트 표면의 detoxification, ${ }^{3}$ 임플란트 근단 절 제(apicoectomy), ${ }^{6}$ 임플란트 제거 ${ }^{7}$ 등. RPI의 치료 목표 는 감염을 감소시켜 병소를 해결하고 궁극적으로 임플 란트를 유지 시키는 것이다.

$\mathrm{RPI}$ 의 많은 증례들이 원인과 성공적인 치료에 대해 보고하고 있으나 대부분 경험적이었으나, 2011년 Chan 등 $^{8}$ 은 이러한 양호한 치료 예후에 근거하여 decisionmaking guideline을 소개하였다. 소개된 지침에 따르면, 임플란트의 동요도가 없고 근단부 병소에 접근 가능하 며, 병소의 크기가 $5 \mathrm{~mm}$ 이상인 경우 임플란트 표면의 detoxification을 동반한 차폐막을 이용한 골이식을 추 천하였다. 본 연구에서는 근관치료가 실패한 상악 우 측 제 2 소구치 부위에 임플란트 식립 후 발생한 $\mathrm{RPI}$ 를 implant surface detoxification과 차폐막을 이용한 골이 식을 동반하여 치료 성공한 7년간의 장기적 결과를 보 고하고자 한다.

\section{증례 보고}

이 증례는 2006년 2월 상악 우측 제2소구치의 근관치 료 실패로 발치 및 임플란트를 위해 부산대학교 치과병 원 치주과에 의뢰된 48세 남성환자에 대한 증례이다. 전 신적 특이소견은 없었으며 중등도의 만성치주염과 불 량한 구강 상태 보이고 있었다. 해당 치아의 근단부에 큰 방사선 투과상 병소가 치근단 사진에 관찰되었고, 구 강 내 배농 및 종창 관찰되어 발치 후 delayed approach 로 임플란트 식립 하기로 결정하고, 발치 및 골내 소파 시행하였다. 4 개월 후, 임플란트 식립 위해 골 삭제 중 큰 골내 결손부가 기존의 치근단 병소와 비슷한 형태 로 탐지되어 임플란트 식립 하지 못하고(Fig. 1A, 2A), 골내 병소 소파 및 이종골 $\left(\mathrm{BBP}^{\circledR}\right.$, Oscotec Co., Seoul, Korea)을 이용한 골이식술을 시행하고 봉합하였다. 치 유과정은 특이사항 없이 진행되었다. 2007년 2월 임플 란트 재식립을 시도하였다. 2단계법으로 Branemark
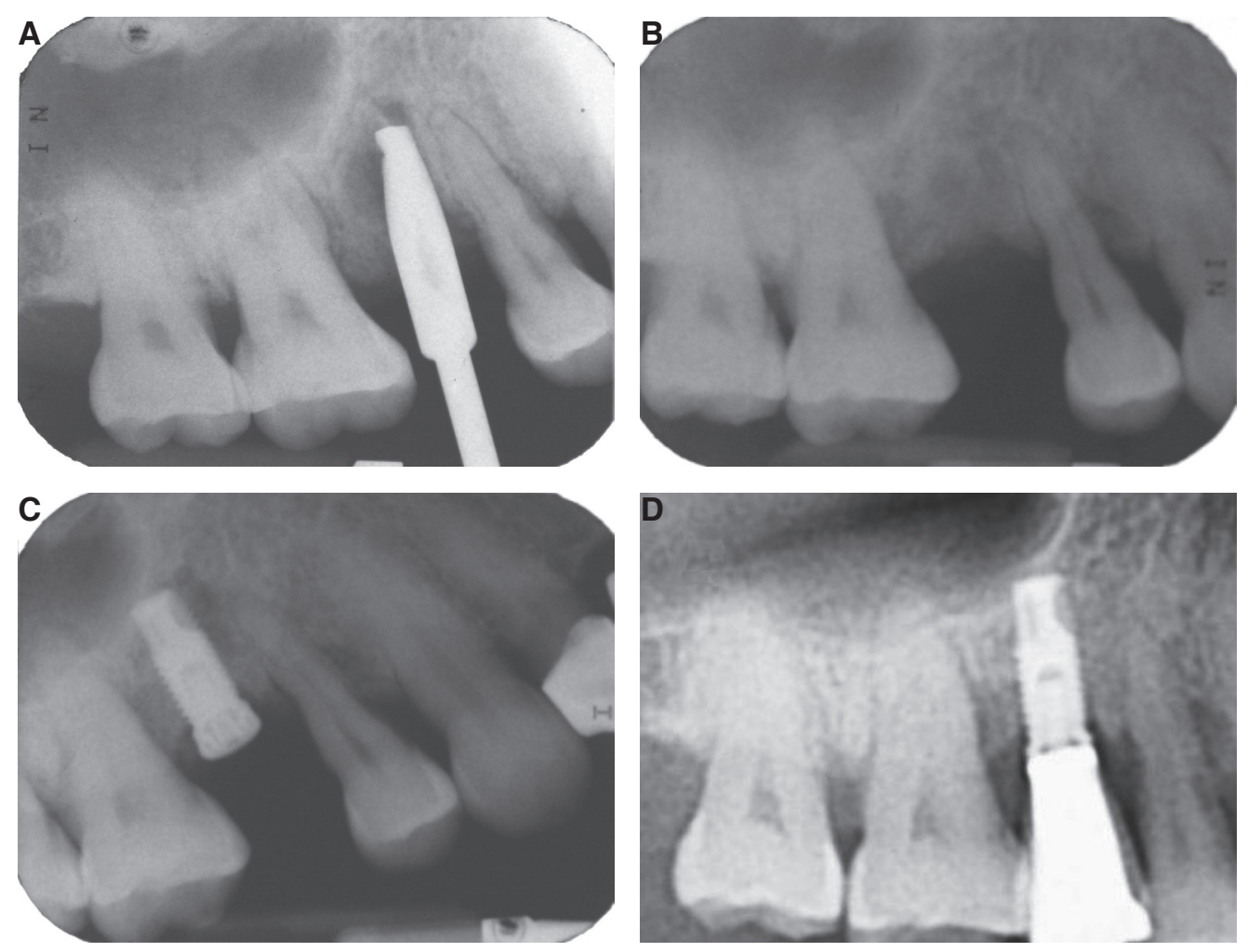

Fig. 1. Radiographs of upper right second premolar region. (A) At first trial for implant installation. Note a radiolucency of apex of implant drill, (B) Second trial for implant installation 8 months after bone graft, (C) Just before second surgery. A radiolucent lesion was observed the apex of fixture, (D) 7 year after treatment of RPI, radiopacity was increased and there was no radiolucency around the fixture. 

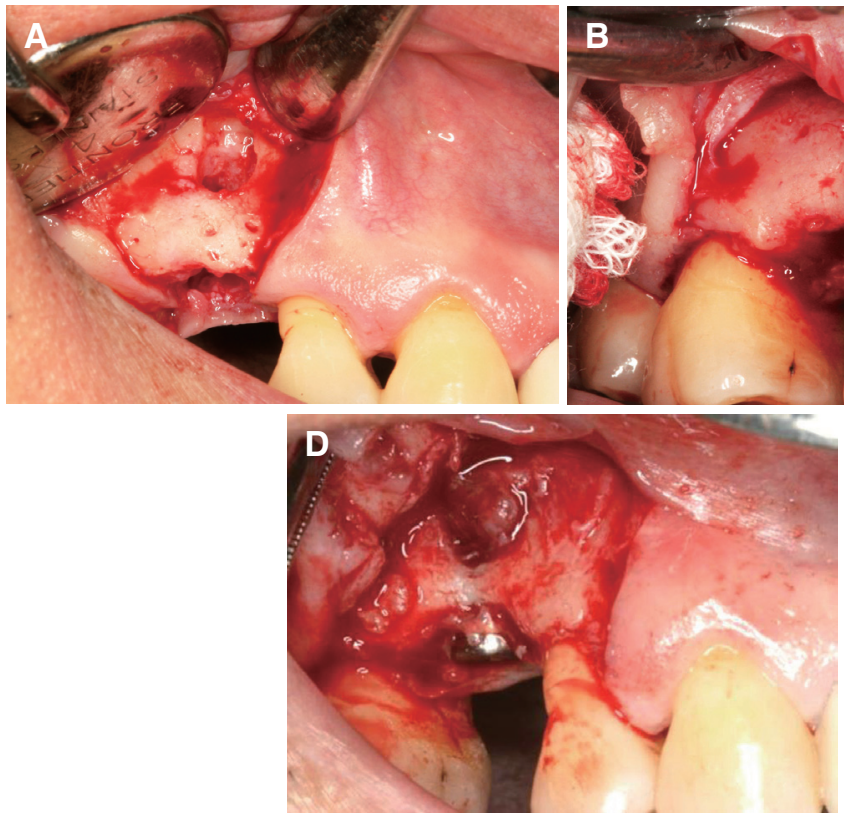
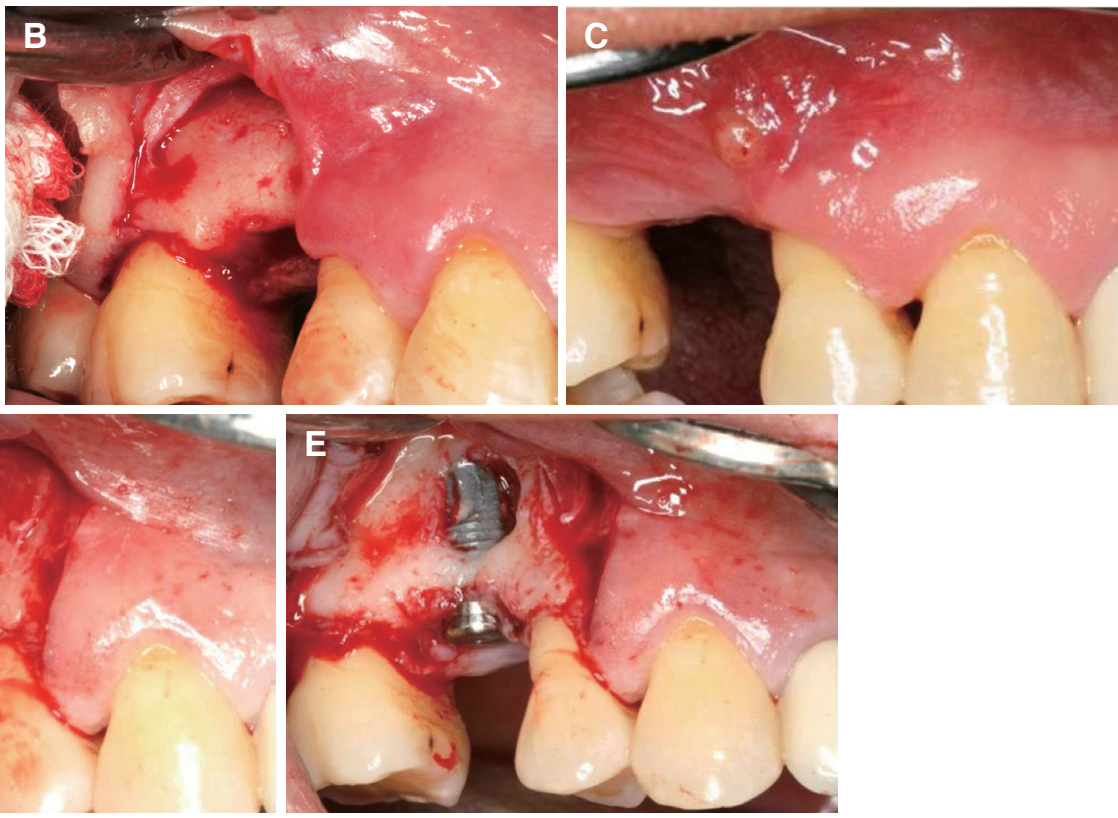

Fig. 2. Clinical view of upper right second premolar region. (A) At first trial for implant installation. Note a bone defect near the root apex area, (B) Second trial for implant installation 8 months after bone graft. The buccal cortical plate was resistant to moderate pressure with an instrument, (C) Just before second surgery, a fistula was observed around the apex of fixture. The lesion was diagnosed as retrograde peri-implantitis. After flap elevation (D) and after debridement of granulation tissue in the bone defect and on the fixture (E). Note the fenestration type bone defect and coronal bony support.

system implant MK III, Groovy (Nobel Biocare AB, Gothenburg, Sweden) $4 \mathrm{~mm}$ 직경, $10 \mathrm{~mm}$ 길이로 식 립 하였다. 식립 시 골 이식한 부위 확인 위해 전층판막 형성하여 확인 시 협측 피질골은 기구 탐침에 저항할 정도의 양호한 회복양상을 보였다(Fig. 1B, 2B). 7 개월 후 2 차 수술 직전 협측 치은의 누공이 관찰되었고(Fig. $2 \mathrm{C}$ ), 치근단 방사선사진에서 이전의 병소와 동일한 위 치에 방사선투과성의 병소가 관찰되었다(Fig. 1C). 환 자는 임상적 불편감이나 증상이 없었으며, 임플란트 동 요도 없이 fixture의 치관측의 골융합은 건전한 양상을 보였다. 역행성 임플란트 치근단병소로 진단하고 임플 란트 표면의 detoxification과 차폐막과 골이식재 이용 한 골유도재생술과 함께 2차 수술 계획하였다. 국소마 취 후 협설 측의 열구절개 및 제1소구치 근심측의 수직 절개 동반한 전층판막을 형성하였다(Fig. 2D). Titanium curette (Hu-Friedy, Chicago, IL, USA)을 이용하여 골 내 병소와 임플란트 표면의 debridement를 시행하였다. fenestration 형태(가로 $5 \mathrm{~mm}$, 세로 $6 \mathrm{~mm}$ )의 골 내 병 소 확인되었고(Fig. 2E), 임플란트 표면의 detoxification 을 위해 $0.12 \%$ 클로르헥시딘 용액(헥사메딘 ${ }^{\circledR}$, 부광약
품, 한국)과 식염수에 적신 거즈로 교대로 표면을 문지 르고, 접근성이 부족한 부위는 헥사메딘과 식염수 교대 로 충분한 시간 주수하여 최대한 detoxification을 도모 하였다. 이후 fenestration 형태의 골결손부에 차폐막과 연조직 붕괴방지를 위해 $\mathrm{BBP}^{\circledR}$ 충전하고 흡수성 차폐막 (Resolut $^{\circledR}$, W.L. Gore \& Associates, AZ, USA)으로 피 개하여 골유도재생술 시행하였다. 상부 지대주 연결하 고 판막은 4-0 Vicryl suture로 봉합하고, amoxicillin 500 $\mathrm{mg}$, acetaminophen $500 \mathrm{mg}$ 하루 3회, 5일간 투약하였 다. 술 후 4주간 $0.12 \%$ 클로르헥시딘 용액 하루 2 번 사 용하였고, 수술 1 주 후 봉합사 제거하였다. 이후 치유양 상의 특이사항 없었으며 차폐막 노출 등의 합병증도 나 타나지 않았다. 2 달 후 implant stability quotient (ISQ) 를 Ostell ${ }^{\circledR}$ (Osstell, Goteborg, Sweden)로 측정하였을 때, 80 이상으로 측정되어 통상적인 임플란트 보철과정 진행 하였다. 이후 처음 2 년간은 3 개월 간격으로, 이후 6 개월 간격으로 유지 관리하여 7년까지 추가적 염증 소 견이나 방사선학적 병소 관찰되지 않으며 기능적으로 잘 유지되고 있다(Fig. 1D). 


\section{고찰}

임플란트의 많은 합병증이 보고되고 있고, RPI의 문 제도 최근 20 여년간 계속 보고되고 있다. 치근단병소 경 험이 있는 발치부위 또는 치근단 병소와 인접한 임플란 트가 수술 후 RPI 발생이 더 많다는 보고가 있다. ${ }^{4}$ 근관 치료 후 치근단 조직의 조직학적 분석에 따르면, 방사선 적으로 양호한 치근단 회복을 보이는 경우도 조직학적 으로 염증 또는 잔존하는 미생물이 자주 관찰된다고 보 고하였다. ${ }^{9}$ 골내의 병소는 피질골 또는 피질골과 해면골 의 경계부의 파괴가 발생해야만 방사선적인 판별이 가 능하고, ${ }^{10}$ 심지어 tomogram 또는 CT scan 영상도 이러 한 초기 병소를 진단하기는 어려울 수 있다. ${ }^{11}$ 그러므로, 임상적으로 증상이 없거나 미약한 증상을 동반한 치근 단 병소도 임플란트 계획 전에 소홀이 생각해서는 안되 며, 임플란트 식립부위 인접한 치아의 근관 상태의 꼼꼼 한 평가가 필요할 것이다. 특히 불완전한 근관치료나 의 심 가는 근관상태를 보이는 치아의 철저한 감별진단이 필수적이며, 필요 시 치수생활력 검사도 반드시 실시하 여야 할 것이다.

만약 RPI로 진단된 병소가 관찰된다면 무엇보다도 임 플란트의 안정성(stability)에 대한 평가가 중요하다. 만 약 임플란트의 동요도가 관찰된다면 더 이상 임플란트 의 유지는 불가능하며 제거되어야 한다. 임플란트 제거 시 철저한 골 내 소파로 병소 주위의 박테리아 감염의 위험을 감소시켜야 한다. 항생제 처방만으로 박테리아 감염 해소에 충분하지 못하므로 외과적으로 철저한 소 파가 필수적이다.

임플란트가 안정적으로 유지된다면, 이러한 임플란 트 안정성을 평가하는 데는 ISQ가 상당한 근거를 제 시해 준다. 본 증례에서도 골유도재생술 2 개월 경과 후 ISQ 80이상을 확인하고 즉시 보철과정을 진행할 수 있 었다. 임플란트 유지가 가능하다고 판단되면 치근단 병 소의 철저한 소파와 임플란트 표면의 detoxification, 골 유도재생술 등의 다양한 접근법을 고려할 수 있다. 외과 적 치료방법 중에 골이식재 사용에 대한 의견은 다양할 수 있으나 본 증례에서는 골내 병소의 크기가 컸기 때문 에 조직 재생을 위한 비계(scaffold) 역할과 차폐막과 연 조직의 붕괴를 방지하기 위해 골이식재를 적용하였다. Chan 등 ${ }^{8}$ 의 연구에서도 $5 \mathrm{~mm}$ 이상의 큰 골결손부에서 는 차폐막을 동반한 골이식술을 추천하였다. Melcher ${ }^{12}$ 가 소개한 조직유도재생술(guided tissue regeneration)
의 개념은 세포 성장을 구분하여 선택성을 부여하기 위 해 차폐막을 사용하였다. 치근단 수술에서 차폐막이 적 용되어 치유기간을 줄여주고 골재생을 증진시킨 좋은 증례들이 보여지고 있다. 치근단 병소가 큰 경우 특히 치유가 불량할 수 있으므로 차폐막의 사용이 더 도움이 될 것이다. ${ }^{13}$ 본 증례에서, 첫 번째 임플란트 시도 시에 잔존하고 있던 큰 근관병소로 인해 임플란트 식립에 실 패하고 차폐막을 사용하지 않고 골이식술만 시행하였 으나 임플란트 식립 이후 골 회복 양상이 불량하여 다시 RPI가 발생한 것도 이러한 맥락에서 생각해 볼 수 있을 것이다.

임플란트 표면의 detoxification은 재골융합(reosseointegration)을 위해 필수적이며 이를 위해 다양한 방법 들이 소개되고 있다 ${ }^{14-16}$ : air-powder abrasive 적용, citric acid, tetracycline, chlorhexidine, normal saline 등의 약 제 적용, 레이져의 적용, 여러 방법의 병용 등. 그러나 어 떠한 한가지 방법이 더 우수한 임상적 결과를 보고하 지는 못하였다. ${ }^{17}$ 특히 다양한 방법의 효과를 비교한 동 물실험결과 클로르헥시딘과 식염수를 거즈에 적셔 사 용하여도 다른 방법과 유사한 수준의 골재생이 가능하 였다. ${ }^{18}$ 이에 본 증례에서는 쉽게 적용가능하며 충분한 detoxification의 효과를 보여주는 클로르헥시딘과 식염 수 교차 적용으로 임플란트 표면 처리를 시도하였다. 이 방법으로 임플란트 치근단 부위 병소의 임상적, 방사선 적인 골재생을 도모할 수 있었으며 이러한 골재생의 결 과는 7년 동안 안정적으로 유지될 수 있었다.

\section{결론}

부분 무치악 임플란트 증례에서 인접치아의 근관 상 태에 대한 면밀한 평가가 필요할 것이다. 만약 RPI로 진 단된 경우, 임플란트 고정체의 치관부가 골융합이 유지 되며 동요도가 없다면 외과적 접근법으로 골재생을 유 도하여 임상적으로 성공적인 임플란트로 장기적으로 유 지가능 할 것으로 생각된다.

\section{Acknowledgements}

본 연구는 2013년도 부산대학교 치과병원 임상연구비 지원으로 이루어졌음. 


\section{References}

1. Quirynen M, Gijbels F, Jacobs R. An infected jawbone site compromising successful osseointegration. Periodontol 2000 2003;33:129-44.

2. Reiser GM, Nevins M. The implant periapical lesion: etiology, prevention, and treatment. Compend Contin Educ Dent 1995;16:768, 770, 772 passim.

3. Ayangco L, Sheridan PJ. Development and treatment of retrograde peri-implantitis involving a site with a history of failed endodontic and apicoectomy procedures: a series of reports. Int J Oral Maxillofac Implants 2001;16:412-7.

4. Quirynen M, Vogels R, Alsaadi G, Naert I, Jacobs $\mathrm{R}$, van Steenberghe D. Predisposing conditions for retrograde peri-implantitis, and treatment suggestions. Clin Oral Implants Res 2005;16:599-608.

5. Lin S, Mayer Y. Treatment of a large periradicular lesion of endodontic origin around a dental implant with enamel matrix protein derivative. J Periodontol 2007;78:2385-8.

6. Dahlin C, Nikfarid H, Alsén B, Kashani H. Apical peri-implantitis: possible predisposing factors, case reports, and surgical treatment suggestions. Clin Implant Dent Relat Res 2009;11:222-7.

7. Flanagan D. Apical (retrograde) peri-implantitis: a case report of an active lesion. J Oral Implantol 2002;28:92-6.

8. Chan HL, Wang HL, Bashutski JD, Edwards PC, $\mathrm{Fu} \mathrm{JH}, \mathrm{Oh}$ TJ. Retrograde peri-implantitis: a case report introducing an approach to its management. J Periodontol 2011;82:1080-8.

9. Green TL, Walton RE, Taylor JK, Merrell P. Radiographic and histologic periapical findings of root canal treated teeth in cadaver. Oral Surg Oral Med Oral Pathol Oral Radiol Endod 1997;83:707-11.
10. van der Stelt PF. Experimentally produced bone lesions. Oral Surg Oral Med Oral Pathol 1985;59:30612.

11. Velvart P, Hecker H, Tillinger G. Detection of the apical lesion and the mandibular canal in conventional radiography and computed tomography. Oral Surg Oral Med Oral Pathol Oral Radiol Endod 2001;92:682-8.

12. Melcher AH. On the repair potential of periodontal tissues. J Periodontol 1976;47:256-60.

13. Tsesis I, Rosen E, Tamse A, Taschieri S, Del Fabbro M. Effect of guided tissue regeneration on the outcome of surgical endodontic treatment: a systematic review and meta-analysis. J Endod 2011;37: 1039-45.

14. Mailoa J, Lin GH, Chan HL, MacEachern M, Wang HL. Clinical outcomes of using lasers for peri-implantitis surface detoxification: a systematic review and meta-analysis. J Periodontol 2014;85:1194-202.

15. Park JB. Treatment of peri-implantitis with deproteinised bovine bone and tetracycline: a case report. Gerodontology 2012;29:145-9.

16. Zablotsky MH, Diedrich DL, Meffert RM. Detoxification of endotoxin-contaminated titanium and hydroxyapatite-coated surfaces utilizing various chemotherapeutic and mechanical modalities. Implant Dent 1992;1:154-8.

17. Claffey N, Clarke E, Polyzois I, Renvert S. Surgical treatment of peri-implantitis. J Clin Periodontol 2008;35:316-32.

18. Schou S, Holmstrup P, Jørgensen T, Skovgaard LT, Stoltze K, Hjørting-Hansen E, Wenzel A. Implant surface preparation in the surgical treatment of experimental peri-implantitis with autogenous bone graft and ePTFE membrane in cynomolgus monkeys. Clin Oral Implants Res 2003;14:412-22. 


\section{역행성 임플란트 근단병소 주위염(Retrograde Peri-implantitis) 치료의 7년 관찰}

\section{이주연*}

부산대학교 치의학전문대학원 치주과학교실

역행성 임플란트 근단병소 주위염은 임상증상을 동반한 근단부의 방사선 투과성 병소로 정의되며 임플란트 식립부위 또는 인접한 치아의 잔존하고 있는 감염에서 유래한 세균감염, 골 삭제시의 열 발생 등의 다양한 원인에 의해 야기될 수 있고, 다양한 치료방법으로 임플란트를 제거하지 않고 유지할 수 있는 증례들이 보고되고 있다. 본 증례에서는 근관 치료 실패로 발치한 상악 우측 제2소구치 부위에 식립한 임플란트에서 발생한 역행성 임플란트 근단병소 주위염을 표 면의 detoxification과 차폐막과 골이식재를 동반한 골유도재생술로 해결하여 기능을 회복하였으며, 7 년간 장기적으로 안정적으로 유지되고 있는 증례에 대해 보고하고자 한다.

(구강회복응용과학지 2014;30(3):295-64)

주요어: 임플란트 주위염; 골이식술; 골재생; 차폐막 